\title{
Evaluation of the relationship between HbA1c values of pregnant women with gestational diabetes and anthropometric measurements of their newborn
}

\author{
Gestasyonel diyabetli gebelerin HbA1c değerleri ile yenidoğanlarının antropometrik ölçümleri \\ arasındaki ilişkinin değerlendirilmesi
} Birgül Deniz Doğan ${ }^{1}$, Emin Pala $^{2}$, Süleyman Ersoy ${ }^{2}$, Murat Doğan ${ }^{3}$

\begin{abstract}
Aim: In our study, we aimed to evaluate the relationship between the HbAlc values of pregnant women who were diagnosed with gestational diabetes mellitus (GDM) and the anthropometric measurements of their newborns.

Methods: 200 pregnant women with GDM between the ages of 18 and 43 with sufficient data were accepted to our study. Also, 200 healthy pregnant women formed the control group. The data of both groups were statistically compared.

Results: Gravidity of pregnant women was 1-8 and parity 1-7 and all between 27-42 gestational weeks. HbA1c values ranged from 4.3 to 8.3 . The height of the babies was between 30 and $57 \mathrm{~cm}$, birth weight between 800 and 4760 grams, and head circumference between 22 and $65 \mathrm{~cm}$. While 1st minute apgar values varied between 2 and 9,5 th minute apgar values varied between 4 and 10 . While $55.3 \%$ of the pregnant women had a normal birth, $44.7 \%$ of them had cesarean section. $95.5 \%$ of HbA1c values were less than 6.5 and $4.5 \%$ of them were at least 6.5 . $45 \%$ of the newborns were girls and $55 \%$ were boys. $7 \%$ were low birth weight, $87 \%$ normal weigh and $6 \%$ macrosomic. While $21.5 \%$ of newborns had complications, $78.5 \%$ had no complications.

Conclusion: The complication rate was higher in pregnant women with GDM and cesarean rate was higher due to increasing birth weight in our study. Further, multi-center and prospective studies may provide new perspectives for prevention of GDM and its complications.
\end{abstract}

Keywords: Gestational Diabetes Mellitus, HbA1c, Newborns
${ }^{1}$ Mucur State Hospital Family Medicine Clinic, Kırşehir, Turkey.

${ }^{2}$ Health Sciences University, Ümraniye Training and Research Hospital, Department of Family Medicine, Istanbul, Turkey.

${ }^{3}$ Health Sciences University, Kurşehir Training and Research Hospital, Department of Family Medicine, Kırșehir, Turkey.

BDD: 0000-0002-9197-2459

EP: 0000- 0001- 9189-4342

SE: 0000-0003-0001-9329

MD: 0000-0003-0776-3644

Ethics Committee Approval: This study was approved by the Ethics Committee of the Umraniye Training and Research Hospital (No: B. 10. 1. TKH. 4. 34. H. GP. 0. 01/ 105, Date: May 22, 2019).

Etik Kurul Onayı: Bu çalışma Ümraniye Eğitim ve Araştırma Hastanesi Etik Kurulu'ndan karar no: B. 10. 1. TKH. 4. 34. H. GP. $0.01 / 105$ ve 22.05.2019 tarihinde etik kurul izni alınmıștır.

Conflict of Interest: No conflict of interest was declared by the authors.

Çıkar Çatışması: Yazar çıkar çatışması bildirmemiștir.

Financial Disclosure: The authors declared that this case has received no financial support.

Finansal Destek: Yazarlar bu çalışma için finansal destek almadıklarını beyan etmişlerdir.

Geliş Tarihi / Received: 12.01.2021

Kabul Tarihi / Accepted: 22.03.2021

Yayın Tarihi / Published: 01.04.2021

Sorumlu yazar / Corresponding author:

Emin Pala

Adres/Address: Sağlık Bilimleri Universitesi, Ümraniye E.A.H, Aile Hekimliği Kliniği, Ümraniye, İstanbul, Turkey. e-mail: eminpala72@gmail.com

Tel/Phone: +90 5058326362

Copyright $(\mathcal{C}$ ACEM 


\section{Introduction}

GDM, is an intolerance to carbohydrates at second or third trimester of pregnancy in women without a history of diabetes mellitus, arising due to the hyperinsulinemia and insulin resistance caused by several hormones released from the placenta $[1,2]$. It occurs resulting from failure of pancreas to overcome insulin resistance [3].

Although the incidence is higher in countries where diabetes is more prevalent, usually it is seen in $2-4 \%$ of pregnant women. In our country the prevalence of diabetes is $13.7 \%$ in the population over 20 years old, thus GDM risk is medium. It is known that GDM may lead to many complications both in the mother and the fetus such as pre-eclampsia, hydramnios, macrosomia etc. [4]

One stage or two stage oral glucose tolerance test is the golden standard for diagnosis [5] and insulin is the golden standard in pharmacological therapy [6].

The objective of this study is, to evaluate the relationship between $\mathrm{HbA} 1 \mathrm{C}$ values of pregnant women with GDM and anthropometric measurements of their newborn and compare them with normoglycemic pregnant women.

\section{Material and methods}

This was a retrospective case control study, and it was carried out by evaluation of the data that belong to pregnant women referring to University of Health Sciences, Umraniye Training and Research Hospital between December 2013 and December 2018.

Case group consists of pregnant woman who referred to our hospital for routine follow up and who met any of the following GDM diagnostic criteria:

50 g glucose challenge test $1-\mathrm{hr}$ Plasma Glucose (PG) level $\geq 180 \mathrm{mg} / \mathrm{dl}$,

$50 \mathrm{~g}$ glucose challenge test $1-\mathrm{hr}$ PG $140-180 \mathrm{mg} / \mathrm{dl}$ and exceeding 2 of the 4 cut-off values after $100 \mathrm{~g}$ glucose challenge for OGTT to reach definitive diagnosis of GDM or in $75 \mathrm{~g}$ OGTT without any challenge test exceeded one of the fasting, 1hr or 2-hr cut-off values.

The subjects who had Type I or Type II DM, any other endocrine disease or history of drug use, those with multiple pregnancy and under 18 years old and those with missing medical records were excluded from the study.

Case group was 200 pregnant women who met inclusion criteria regarding GDM diagnosis. A control group was selected randomly among pregnant women who do not have any comorbid disease or history of drug use.

The data of pregnant women with GDM and their newborns are compared with the control group.

\section{Ethics approval}

University of Health Sciences, Umraniye Training \& Research Hospital Clinical Research Ethics Committee has approved the study on 22 May 2019 with B. 10. 1. TKH. 4. 34. H. GP. 0. 01/ 105 decision no and the study had clearance regarding ethical and scientific integrity of the study.

\section{Statistical analysis}

IBM SPSS Statistics 22 (IBM SPSS, Turkey) program is used for statistical analysis in assessment of data obtained from the study. Conformity of the parameters to normal distribution was tested by Shapiro Wilks test. For assessment of study data, in addition to descriptive statistical methods (mean, standard deviation, frequency) comparison of quantitative data and intergroup comparison of parameters with normal distribution were done by using one-way Anova test. Parameters with normal distribution were compared between two groups by
Student $\mathrm{t}$ test, parameters with non-normal distribution were compared between two groups by Mann Whitney $U$ test. Qualitative data were compared by using Chi-square test, Fisher's Exact test, and Continuity (Yates) Correction. The correlation between parameters that are in conformity with normal distribution was studied by using Pearson correlation analysis. $\mathrm{p}<0.05$ is considered significant.

\section{Results}

Our study included 200 pregnant women with GDM diagnosis and 200 pregnant women who served as control group in an age range of 18-43 years and their newborns.

Time span was $27-42$ gestational weeks. Gravidity was 1-8 and parity was $0-7$ and $\mathrm{HbA} 1 \mathrm{c}$ values ranged between 4,38,3 . and in 82 pregnant women the values ranged between $5,7-$ 6,4 . Complications were observed in $21.5 \%$ of the newborns and the remaining newborns were free from complications.

Table 1. Distribution of study parameters.

\begin{tabular}{|c|c|c|}
\hline & Min-Max & Mean \pm SD \\
\hline Age at pregnancy & $18-43$ & $29.14 \pm 5.79$ \\
\hline Gestational week (median) & $27-42$ & $38.08 \pm 2.26(38)$ \\
\hline Gravidity(median) $_{\text {(1) }}$ & $1-8$ & $2.81 \pm 2.32(3)$ \\
\hline Parity $_{\text {(median) }}$ & $0-7$ & $1.33 \pm 1.14(1)$ \\
\hline HbA1c $(n=200)$ & $4.3-8.3$ & $5.61 \pm 0.54$ \\
\hline Height at birth $(\mathrm{cm})$ & $30-57$ & $50.22 \pm 2.89$ \\
\hline Weight at birth (g) & $800-4760$ & $3300.68 \pm 540.95$ \\
\hline Head circumference $(\mathrm{cm})$ & $22-65$ & $34.63 \pm 2.79$ \\
\hline Apgar $1_{\text {(median) }}$ & $2-9$ & $8.73 \pm 0.8(9)$ \\
\hline \multirow[t]{2}{*}{ Apgar 5 (median) } & $4-10$ & $9.8 \pm 0.65(10)$ \\
\hline & $\mathrm{n}$ & $\%$ \\
\hline
\end{tabular}

Gestational week group

Preterm (under 37 weeks)

Term (37-42 weeks)

Post-term (over 42 weeks)

Type of birth

Normal

HbA1c group $(n=200)$

$<6.5$

Treatment $(\mathrm{n}=200)$

Insulin + Diet

Diet

Sex

Female

Male

Birth weight (g) group

Low (under 2500)

Normal (2500-4000)

Macrosomia (above 4000)

348

$$
6
$$

Presence of complication

No

86 
Table 2. Intergroup assessment of study parameters.

\begin{tabular}{|c|c|c|c|}
\hline & $\begin{array}{c}\text { GDM group } \\
\text { (Min-Max)-(Mean } \pm \text { SD) }\end{array}$ & $\begin{array}{c}\text { Control group } \\
\text { (Min-Max)-(Mean } \pm \text { SD) }\end{array}$ & $\mathbf{p}$ \\
\hline $\begin{array}{l}\text { Age at pregnancy } \\
\text { (y) }\end{array}$ & $(20-42)-(30.93 \pm 5.21)$ & $(18-43)-(27.36 \pm 5.81)$ & ${ }^{1} 0.000 *$ \\
\hline $\begin{array}{l}\text { Gestational week } \\
\text { (median) }\end{array}$ & $(27-42)-(37.62 \pm 2.22(38))$ & $(19-42)-(38.54 \pm 2.21(39))$ & ${ }^{2} 0.000 *$ \\
\hline $\begin{array}{l}\text { Gravidity } \\
\text { (median) }\end{array}$ & $(1-40)-(3.2 \pm 2.92(3))$ & $(1-8)-(2.43 \pm 1.41(2))$ & ${ }^{2} 0.000 *$ \\
\hline Parity (median) & $(0-6)-(1.49 \pm 1.03(1))$ & $(0-7)-(1.18 \pm 1.23(1))$ & ${ }^{2} 0.000 *$ \\
\hline $\mathrm{HbA} 1 \mathrm{c}$ & $(4.3-8.3)-(5.61 \pm 0.54)$ & - & - \\
\hline Height at birth & $(30-57)-(49.79 \pm 3.17)$ & $(36-56)-(50.66 \pm 2.51)$ & ${ }^{1} 0.002 *$ \\
\hline Birth weight & $\begin{array}{c}(800-4760)- \\
(3315.72 \pm 599.04)\end{array}$ & $\begin{array}{c}(1265-4310)- \\
(3285.65 \pm 476.88)\end{array}$ & ${ }^{1} 0.579$ \\
\hline $\begin{array}{l}\text { Head } \\
\text { circumference }\end{array}$ & $(22-65)-(34.87 \pm 3.55)$ & $(29.5-46)-(34.4 \pm 1.72)$ & ${ }^{1} 0.092$ \\
\hline Apgar 1 (median) & $(2-9)-(8.63 \pm 0.94(9))$ & $(5-9)-(8.82 \pm 0.62(9))$ & ${ }^{2} 0.002 *$ \\
\hline \multirow[t]{2}{*}{ Apgar 5 (median) } & $(4-10)-(9.74 \pm 0.74(10))$ & $(6-10)-(9.86 \pm 0.53(10))$ & ${ }^{2} 0.014 *$ \\
\hline & $\mathrm{n}(\%)$ & $\mathrm{n}(\%)$ & \\
\hline \multicolumn{4}{|l|}{ Gestational week } \\
\hline Preterm & $30(15)$ & $14(7)$ & \multirow{4}{*}{${ }^{3} 0.005^{*}$} \\
\hline Term & $164(82)$ & $170(85)$ & \\
\hline Postterm & $6(3)$ & $16(8)$ & \\
\hline \multicolumn{3}{|l|}{ Type of birth } & \\
\hline Normal & $87(43.5)$ & $134(67)$ & \multirow{2}{*}{${ }^{3} 0.000 *$} \\
\hline Caesarian & $113(56.5)$ & $66(33)$ & \\
\hline \multicolumn{4}{|l|}{ HbA1c } \\
\hline$\leq 6.5$ & $193(96.5)$ & - & \multirow[t]{2}{*}{ - } \\
\hline$>6.5$ & $7(3.5)$ & - & \\
\hline \multicolumn{4}{|l|}{ Treatment } \\
\hline Insülin+Diet & $107(53.5)$ & - & \multirow[b]{2}{*}{-} \\
\hline Diet & $93(46.5)$ & - & \\
\hline \multicolumn{4}{|l|}{ Sex } \\
\hline Female & $98(49)$ & $82(41)$ & \multirow{2}{*}{${ }^{3} 0.108$} \\
\hline Male & $102(51)$ & $118(59)$ & \\
\hline \multicolumn{4}{|l|}{ Birth weight } \\
\hline Low & $15(7.5)$ & $13(6.5)$ & \multirow{3}{*}{${ }^{3} 0.094$} \\
\hline Normal & $168(84)$ & $180(90)$ & \\
\hline Macrosomia & $17(8.5)$ & $7(3.5)$ & \\
\hline \multicolumn{4}{|l|}{$\begin{array}{l}\text { Presence of } \\
\text { complication }\end{array}$} \\
\hline Yes & $141(70.5)$ & $173(86.5)$ & ${ }^{3} 0.000 *$ \\
\hline No & $59(29.5)$ & 27 (13.5) & \\
\hline
\end{tabular}

The height of the newborns was between 30 and $57 \mathrm{~cm}$, birth weight between 800 and 4760 grams, and head circumference between 22 and $65 \mathrm{~cm}$. While $1^{\text {st }}$ minute apgar values varied between 2 and 9, 5th minute apgar values varied between 4 and 10. Pregnancies have ended at preterm in $11 \%$, term in $83.5 \%$ and post-term in $5.5 \%$ of the pregnant women. $55.3 \%$ of the pregnant women had a normal birth and $44.7 \%$ of them had cesarean section. Only diet was recommended as treatment in $46.5 \%$ of the subjects diagnosed as GDM and the remaining subjects had additional insulin injections. $45 \%$ of the babies were girls and $55 \%$ were boys. $7 \%$ were low birth weight, $87 \%$ normal weight and $6 \%$ had macrosomia (Table 1).

The most common complications were hyperbilirubinemia $(36 \%)$ and transient tachypnea of the newborn $(30,2 \%)$ followed by ASD $(8.1 \%)$, prematurity $(8.1 \%)$, sepsis $(7.0 \%)$, congenital pneumonia $(5.8 \%)$ and VSD (4.7\%).

Mean age, gravidity values, parity values and birth by cesarean section were statistically significantly higher in pregnant women with GDM compared to the control group $(\mathrm{p}<0.001)$. However, gestational week values and height of the newborns at birth were significantly lower than the control group $(\mathrm{p}<0.001)$ (Table 2).

In the newborns of the group with GDM transient tachypnea of the newborn and early neonatal sepsis rates were statistically significantly lower compared to the control group regarding complications. $\quad(\mathrm{p}<0.05)$ However, rate of hyperbilirubinemia was statistically significantly higher compared to the control group $(\mathrm{p}<0.05)$ (Table 3$)$.
Table 3. Intergroup complication rates.

\begin{tabular}{|c|c|c|c|}
\hline \multirow{2}{*}{ Complications } & GDM group & Control group & \multirow{2}{*}{$\mathrm{p}$} \\
\hline & $\mathrm{n}(\%)$ & $\mathrm{n}(\%)$ & \\
\hline $\begin{array}{l}\text { Transient tachypnea of } \\
\text { newborn }\end{array}$ & $13(22)$ & $13(48.1)$ & ${ }^{1} 0.028^{*}$ \\
\hline Atrial septal defect & $5(8.5)$ & $2(7.4)$ & ${ }^{2} 1.000$ \\
\hline Hypoglycemia & $6(10.2)$ & $0(0)$ & ${ }^{2} 0.170$ \\
\hline Small for gestational age & $1(1.7)$ & $0(0)$ & - \\
\hline Large for gestational age & $2(3.4)$ & $0(0)$ & - \\
\hline ventricular septal defect & $3(5.1)$ & $1(3.7)$ & ${ }^{2} 1.000$ \\
\hline Hyperbilirubinemia & $28(47.5)$ & $3(11.1)$ & ${ }^{1} 0.003 *$ \\
\hline Pulmonary hypoplasia & $1(1.7)$ & $0(0)$ & - \\
\hline Congenital cardiac defects & $1(1.7)$ & $0(0)$ & - \\
\hline $\begin{array}{l}\text { Intrauterine growth } \\
\text { retardation }\end{array}$ & $3(5.1)$ & $1(3.7)$ & ${ }^{2} 1.000$ \\
\hline Patent ductus arteriosus & $4(6.8)$ & $2(7.4)$ & ${ }^{2} 1.000$ \\
\hline Sepsis & $2(3.4)$ & $1(3.7)$ & ${ }^{2} 1.000$ \\
\hline Tricuspid insufficiency & $1(1.7)$ & $1(3.7)$ & - \\
\hline Inguinal hernia & $1(1.7)$ & $0(0)$ & - \\
\hline Prematurity & $5(8.5)$ & $2(7.4)$ & ${ }^{2} 1.000$ \\
\hline Brachial plexus injury & $1(1.7)$ & $0(0)$ & - \\
\hline Low birth weight & $2(3.4)$ & $1(3.7)$ & ${ }^{2} 1.000$ \\
\hline Intubation & $1(1.7)$ & $0(0)$ & - \\
\hline $\begin{array}{l}\text { Pneumothorax: decreased } \\
\text { aeration of lungs }\end{array}$ & $3(5.1)$ & $0(0)$ & ${ }^{2} 0.549$ \\
\hline Asphyxia & $1(1.7)$ & $0(0)$ & - \\
\hline Congenital pneumonia & $3(5.1)$ & $2(7.4)$ & ${ }^{2} 0.647$ \\
\hline Exitus & $2(3.4)$ & $0(0)$ & - \\
\hline $\begin{array}{l}\text { Respiratory distress } \\
\text { syndrome }\end{array}$ & $2(3.4)$ & $1(3.7)$ & ${ }^{2} 1.000$ \\
\hline Early neonatal sepsis & $1(1.7)$ & $5(18.5)$ & ${ }^{2} 0.011 *$ \\
\hline Urinary tract infection & $1(1.7)$ & $0(0)$ & - \\
\hline Thrombocytopenia & $1(1.7)$ & $1(3.7)$ & - \\
\hline Clavicular fracture & $1(1.7)$ & $0(0)$ & - \\
\hline Aorta coarctation & $0(0)$ & $1(3.7)$ & - \\
\hline Down syndrome & $0(0)$ & $1(3.7)$ & - \\
\hline $\begin{array}{l}\text { Spina bifida: nerve damage } \\
\text { in spinal cord }\end{array}$ & $0(0)$ & $1(3.7)$ & - \\
\hline Other complications & $0(0)$ & $3(11.1)$ & ${ }^{2} 0.029 *$ \\
\hline
\end{tabular}

Presence of complications, type of birth and birth weight did not affect HbA1c values statistically in both groups (Table 4).

In subjects with GDM, there was no statistical correlation between $\mathrm{HbA} 1 \mathrm{c}$ values and age, gravidity, parity of the subjects and birth weight of the newborns ( $p>0.05)$.

Mean age of the mothers of newborns with complications was higher than the mothers of newborns without complication; birth weight of newborns with complications was lower than newborns without any complications $(\mathrm{p}<0.001)$.

Insulin treatment in subjects with $\mathrm{HbA1c}<5.7(45 \%)$ was statistically significantly lower than subjects with $\mathrm{HbA} 1 \mathrm{c}$ $5,7-6,4(59,8 \%)$ and HbA1c $>6,5(100 \%)(p=0.024)$.

There was no statistically significant difference regarding the rate of complications and birth weights of the newborns in mothers with GDM who are treated with insulin or not (Table 5). 
Table 4. Assessment of HbA1c values in GDM group according to the presence of complication, type of birth and birth weight.

\begin{tabular}{lccc}
\multirow{2}{*}{ GDM group } & \multicolumn{2}{c}{ HbA1c } & $\mathrm{p}$ \\
\cline { 2 - 4 } & Min-Max & Mean \pm SD & \\
\hline Presence of complication & & & $0.459^{1}$ \\
No & $4.5-7.2$ & $5.59 \pm 0.49$ & \\
Yes & $4.3-8.3$ & $5.65 \pm 0.65$ & \\
\hline Type of birth & & & $0.523^{1}$ \\
Normal & $4.3-8.3$ & $5.58 \pm 0.56$ & \\
Caesarian & $4.5-7.4$ & $5.63 \pm 0.53$ & \\
\hline Birth weight group & & & $0.167^{2}$ \\
Low & $5.1-8.3$ & $5.77 \pm 0.78$ & \\
Normal & $4.3-7.2$ & $5.58 \pm 0.5$ & \\
Macrosomia & $4.6-7.4$ & $5.78 \pm 0.68$ & \\
\hline
\end{tabular}

There is no significant correlation between $\mathrm{HbA} 1 \mathrm{c}$ and height and head circumference of the newborns $(\mathrm{r}=0.118$, $\mathrm{p}=0.096$ and $\mathrm{r}=0.020, \mathrm{p}=0.774$ respectively).

Table 5. Assessment of presence of complications according to insulin treatment in subjects with GDM.

\begin{tabular}{|c|c|c|c|}
\hline & \multicolumn{2}{|c|}{ Insulin treatment } & \multirow[b]{2}{*}{$\mathrm{p}$} \\
\hline & Yes $(\mathrm{n} \%))$ & No $(\mathrm{n} \%))$ & \\
\hline Presence of complication & & & \\
\hline No & $70(65.4)$ & $71(76.3)$ & ${ }^{1} 0.091$ \\
\hline Yes & $37(34.6)$ & $22(23.7)$ & \\
\hline Birth weight. Mean $\pm S D$ & $3303.74 \pm 659.94$ & $3329.49 \pm 523.51$ & ${ }^{2} 0.763$ \\
\hline
\end{tabular}

\section{Discussion}

In the literature it is reported that advanced age is a risk factor for GDM in pregnancy. In a Canadian study by Denice et al. 1,109,605 pregnant women were assessed and GDM prevalence was found as $10 \%$ in women older than 30 [7]. In Finland, Lamminpää et al. studied 230,003 pregnant women over 35 years old with GDM and 5532 non-diabetic pregnant women younger than 35 years old and have found that GDM risk increases by increasing age [8]. In our study, mean age, gravidity, and parity values of women with GDM were found to be statistically significantly higher than the control group.

GDM is a significant health issue since it substantially impacts maternal and perinatal morbidity. In a study by Carolan $\mathrm{M}$ et al. it is observed that maternal hypertension, pre-eclampsia rates and interventions such as caesarian have increased in women with GDM [9] Also in our study C/S ratio (56.5\%) of pregnant women with GDM was significantly higher than the control group (33\%).

Measuring HbA1c in GDM patients is a controversial issue. The International Experts Committee on diabetes has reported that individuals with a HbA1c value 5.7-6.4\% (39-46 $\mathrm{mmol} / \mathrm{mol}$ ) are at high risk for diabetes and should be included into the prevention programs [3]. In our study, HbA1c was 5.7$6.4 \%$ in $82(41 \%)$ pregnant women and $\geq 6.5$ in $9(4.5 \%)$ of them. Mean value of HbA1c was 5.61 in pregnant women with GDM.

Macrosomia is a common complication observed in newborns of diabetic mothers and described as birth weight over $4000 \mathrm{~g}$ or more than 90th percentile in population-based growth charts. In the study of Figueroa et al., it is reported that in newborns of patients with borderline gestational diabetes LGA and macrosomia incidence have increased 2 and 1.6 times, respectively. In the study by Bonomo et al. it is reported that even slight alterations in glucose intolerance [10] may lead to excessive growth of the fetus [11]. In our study there was no significant difference between newborns regarding birth weight.

In the literature, correlation between fetal birth weight and maternal is a debated issue. In the study by Coen et al., it is concluded that there is no correlation between maternal $\mathrm{HbA} 1 \mathrm{c}$ and birth weight [12]. In a comprehensive HAPO study, it is stated that plasma glucose level is more relevant in determining birth weight compared to HbA1c values [13]. In another study carried out in Turkey, it is reported that there is a positive and independent correlation between 2 nd trimester maternal $\mathrm{HbA} 1 \mathrm{c}$ values and birth weight [14]. In our study, we could not find any significant relationship between $\mathrm{HbA} 1 \mathrm{c}$ values and birthweight, height at birth and head circumference of the newborns. This may be associated with strict antenatal follow up, proper insulin therapy, diet and exercise.

In some research it is observed that in pregnant women with previous diabetes diagnosis or with high HbA1c values during first trimester, risk of hazardous outcomes such as miscarriage, premature birth, neonatal mortality, fetal anomaly is higher compared to normal pregnancy. And it is reported that risk increases proportionally by increasing $\mathrm{HbA} 1 \mathrm{c}$ values $[15,16]$. In different studies, the incidence of congenital anomalies was found higher in pregnant women with higher HbA1c values $[17,18]$. In our study as well, HbA1c values were significantly higher in diabetic pregnants who had complications compared to those without complications.

It is known that GDM may cause a lot of complications. In a study carried out in Poland the most common complications observed in newborns of the pregnant women with GDM were hyperbilirubinemia $(17.3 \%)$, hypoglycemia (15.6\%), congenital defects $(4.3 \%$ - most commonly cardiac anomalies) [19]. In our study the most common complications among those with GDM were hyperbilirubinemia $(47.5 \%)$, transient tachypnea of the newborn (22\%), hypoglycemia (10.2\%)

Advanced maternal age is among risk factors for GDM. In the study of Lamminpää et al;; it was observed that the advanced age of the mother increased the risk of prematurity, fetal mortality, and admission of the newborn to neonatal intensive care unit [9]. Based on this information we have compared the mean age of the pregnant woman with GDM who had complications (32.27 years) and those who did not have any complications (30.36 years). Mean age or the mothers with GDM was significantly higher in those who had complications compared to the ones without complications.

Preterm birth is defined as births occurring before 37th gestational age and GDM is a risk factor for preterm birth. In a study by Beigelman et al. incidence of preterm birth was found as $10 \%$ among 3841 pregnant women with GDM [20]. Moreover, in a study carried out by Heddeson et al. glucose intolerance is found to be related with spontaneous preterm births. In our study preterm birth rate was significantly higher in pregnant women with GDM (15\%) compared to the control group (7\%).

Due to various metabolic disorders occurring in newborns because of maternal diabetes the newborns of diabetic mothers may have lower apgar scores at birth. There are studies also on the contrary. In Israel Bental et al. investigated newborns of 120 pregestational diabetic and 825 gestational diabetic mothers prospectively and have found that APGAR score was higher in newborns of diabetic mothers compared to the newborns of non-diabetic mothers [21]. In our study $1 \mathrm{st}$ minute (8.63) and 5th minute (9.74) mean APGAR scores of the newborns of mother with GDM were found to be statistically lower than the mean APGAR scores of the newborns of nondiabetic mother group (8.82-9.86).

In a study carried out in Turkey it is suggested that HbA1c value >5,4 in pregnant women with GDM may be a predictor for starting insulin treatment [22]. In our study rate of insulin use in those with $\mathrm{HbA1c}<5.7$ was $45 \%$, it was $58.8 \%$ when the value is between $5.7-6.4$ and $100 \%$ when it is $\geq 6.5$. 
According to these results it is observed that need for insulin increase as $\mathrm{HbA1c}$ value increases.

In our study there was no significant difference in terms of occurrence of complications between pregnant women with GDM who use insulin and who do not. However, in a randomized, multi-center study performed in the USA two groups with slight GDM were compared and in one of the groups normal gestational follow up was sustained and the other group was treated (diet, blood glucose monitoring and insulin when needed). In the treatment group complications such as macrosomia, shoulder dystocia and incidence of sectio was lower [23].

Anthropometric measurements of the newborns were compared in terms of treatment applied to the mothers with GDM diagnosis in Italy by Mello et al.; LGA rate was $18.8 \%$ in mothers treated only by diet; $9.9 \%$ in mothers treated with both diet and insulin and $8.3 \%$ in the control group [24]. Fetal macrosomia is a common adverse infant outcome of GDM if unrecognized and untreated in time. For the infant, macrosomia increases the risk of shoulder dystocia, clavicle fractures and brachial plexus injury and increases the rate of admissions to the neonatal intensive care unit [25] It may be suggested that proper follow up and treatment may decrease macrosomia. In our study, we could not find any significant difference between the birth weights of newborns who were born from pregnant women with GDM who were treated with insulin or not.

Consequently, the complication rate was higher in pregnant women with GDM and cesarean rate was higher due to increasing birth weight in our study. The negative impact of GDM on maternal and fetal morbidity and mortality may be mitigated by diet, insulin treatment and strict antenatal follow up. Further, multi-center and prospective studies may provide new perspectives for prevention of GDM and its complications.

\section{References}

1. Metzger, Boyd E. "Proceedings of the fourth international workshop conference on gestational diabetes mellitus." Diabetes Care 21.2 (1998): B1-B167.

2. Practice Bulletin No. 137, Obstetrics \& Gynecology: August 2013 - Volume 122 - Issue 2 PART 1 - p 406-416 doi: 10.1097/01.AOG.0000433006.09219.f1

3.Diabetes Mellitus ve Komplikasyonlarının Tanı, Tedavi ve İzlem Kılavuzu, Türkiye Endokrinoloji ve Metabolizma Derneği (2019), Ankara.

4. Oğuz A. Gestasyonel Diyabet. KSU Tıp Fak Derg. 2016;11:269.

5. Dodd JM, Crowther CA, Antoniou G, Baghurst P, Robinson JS. Screening for gestational diabetes: the effect of varying blood glucose de) nitions in the prediction of adverse maternal and infant health outcomes. Aust N Z J Obstet Gynaecol. 2007;47:307-12.

6. American Diabetes Association. Standards of medical care in diabetes. Diabetes Care. 2010;33:11-61.

7. Coustan, D. R., and L. Jovanovic. "Gestational diabetes mellitus: glycemic control and maternal prognosis." UpToDate [Internet]. Waltham, Mass.: [Cited 2014 September 12]. Available from: URL: http:/ www.uptodate.com/contents/search.

8. Denice S. Feig, Jeremiah Hwee, Baiju R. Shah, Giliian L. Booth, Arlene S. Bierman, Lorraine L. Lipscombe Trends in Incidence of Diabetes in Pregnancy and Serious Perinatal Outcomes A Large, Population-Based Study in Ontario, Canada, 1996-2010. Diabetes Care. 2014;37:15901596.

9. Lamminpää R, Vehviläinen-Julkunen K, Gissler M, Selander T, Heinonen S. Pregnancy outcomes in women aged 35 years or older with gestational diabetes- a registry-based study in Finland. J Matern Fetal Neonatal Med. 2014;8:1-5.

10. Figueroa D, London MB, Mese L, Spong CY, Ramin SM, Casef B, Wapner RJ, Varner MW, Thorp JM. Relationship
Between 1-Hour Glucose Challenge Test Results and Perinatal Outcomes. Obstet Gynecol. 2013;121:1241-7.

11. David CS, Lash RW. University of Michigan Medical School, Ann Arbor, Michigan. Diagnosis and Management of Gestational Diabetes Mellitus, Am Fam Physician. 2009;80:57-62.

12. Coen RW, Porreco R, Cousins L, Sandler JA. Postpartum glycosylated hemoglobin levels in mothers of large--for-gestational age infants. Am J Obstet Gynecol. 1980;136:380-2.

13. Lowe LP, Metzger BE, Dyer AR, Lowe J, McCance DR, Lappin TR, et al. Hyperglycemia and Adverse Pregnancy Outcome (HAPO) Study: associations of maternal A1C and glucose with pregnancy outcomes. Diabetes Care. 2012;35:574- 80.

14. Karcaaltincaba D, Yalvac S, Kandemir O, Altun S. Glycosylated hemoglobin level in the second trimester predicts birth weight and amniotic fluid volume in non-diabetic pregnancies with abnormal screening test. J Matern Fetal Neonatal Med. 2010;23:1193-9.

15. Culligan PJ, Myers JA, Goldberg RP, Blackwell L, Gohmann $\mathrm{SF}$, Abell TD. Elective cesarean section to prevent anal incontinence and brachial plexus injuries associated withmacrosomia-a decisionanalysis. Int Urogynecol J. 2005;16:1928.

16. Rouse DJ, Owen J, Goldenberg RL, et al. The effectiveness and costs of elective cesarean delivery for fetal macrosomia diagnosed by ultrasound. JAMA 1996;276:1480-6.

17. Reece EA, Homko CJ, Wu Y-K. Multifactorial basis of the syndrome of diabetic embryopathy. Teratology. 1996;54:171-82.

18. Reece EA. Homko CJ. Why do diabetic women deliver malformed infants? Clin Obstet Gynecol. 2000;43:32-45.

19. Malinowska-Polubiec A, Czajkowski K, Sotowska A. Pregnancy and delivery course in patients with gestational diabetes mellitus. Ginekol Pol. 2003;74:1200.

20. . Beigelman A, Wiznitzer A, Shoham-Vardi I, Vardi H, Holtcberg G, Mazor M. [Premature delivery in diabetes: etiology and risk factors]. Harefuah. 2000;138:919-23.

21. Bental Y, Reichman B, Shiff Y, Weisbrod M, Boyko V, Lerner-Geva L, Mimouni FB. Impact of maternal diabetes mellitus on mortality and morbidity of preterm infants (24-33 weeks' gestation). Pediatrics. 2011;128:848-55.

22. Bakiner O, Bozkirli E, Ozsahin K, Sariturk C, Ertorer E. Risk Factors That can Predict Antenatal Insulin Need in Gestational Diabetes. J Clin Med Res. 2013;5:381-8.

23. Werner EF, Hauspurg AK, Rouse DJ. A cost-benefit analysis of low-dose aspirin prphylaxis for the prevention of preeclampsia in the United States. Obstet Gynecol. 2015;126:1242-50.

24. Mello G, Parretti E, Mecacci F, Carbone C, Lucchetti R, Lagazio C, Pratesi M, Scarselli G. Anthropometric features in infants of mothers with gestational diabetes: relationship with treatment modalities. Biol Neonate.1997;72:22-7.

25. Kc K, Shakya S, Zhang H. Gestational diabetes mellitus and macrosomia: a literature review. Ann Nutr Metab. 2015;66 Suppl 2:14-20. 